\title{
Waterlogging effects on some antioxidant enzymes activities and yield of three wheat promising lines
}

\author{
Fereshteh ALIZADEH-VASKASI ${ }^{1}$, Hemmatollah PIRDASHTI $^{2 *}$, Ali CHERATI ARAEI ${ }^{3}$, Sara SAADATMAND $^{1}$
}

Received May 31, 2018; accepted October 25, 2018.

Delo je prispelo 31. maja 2018, sprejeto 25. oktobra 2018.

\begin{abstract}
Waterlogging is one of the most important environmental stresses that have negative effects on wheat growth and yield. The purpose of this study was to investigate the effect of waterlogging $(0,7,14$ and $21 \mathrm{~d})$ at tillering (ZG21) and stem elongation (ZG31) stages on the content of photosynthetic pigments, proline, malondialdehyde (MDA), antioxidant enzymes, grain yield and yield components of three wheat promising lines (N-93-19, N-93-9 and N-92-9). Increasing waterlogging stress reduce the photosynthetic pigments contents and the activity of catalase enzyme while increase the proline content, MDA, superoxide dismutase and peroxidase enzymes in three wheat genotypes in both tillering and stem elongation stages. Waterlogging also reduced yield and yield components in three wheat genotypes. The results showed that N-92-9 genotype had better response than other two genotypes in all studied traits under waterlogging conditions.
\end{abstract}

Key words: waterlogging stress; antioxidant enzymes; wheat; proline; yield; yield components

\section{IZVLEČEK}

\section{UČINKI ZASTAJANJA VODE V TLEH NA AKTIVNOST NEKATERIH ANTIOKSIDACIJSKIH ENCIMOV IN PRIDELEK TREH OBETAJOČIH LINIJ PŠENICE}

Zastajanje vode $\mathrm{v}$ tleh je eden od najpomembnejših okoljskih stresov, ki ima negativni učinek na rast in pridelek pšenice. Namen raziskave je bil preučiti učinke zastajanja vode $\mathrm{v}$ tleh $(0,7,14$ in 21 dni) $v$ fazah razraščanja $(Z G 21)$ in bilčenja (ZG31), prolina, malondialdehida (MDA), antioksidacijskih encimov, pridelek zrnja in komponenete pridelka treh obetajočih linij pšenice (N-93-19, N-93-9 in N-92-9). Povečanje stresa zaradi zastoja vode $\mathrm{v}$ tleh zmanjša vsebnost fotosinteznih pigmentov in aktivnost katalaze in poveča vsebnost prolina in MDA, poveča aktivnost superoksid dismutaze in peroksidaze pri vseh treh genotipih pšenice $\mathrm{v}$ vseh preučevanih fazah razvoja. Zastajanje vode $v$ tleh je tudi zmanjšalo pridelek in njegove komponente pri vseh treh genotipih pšenice. Rezultati so pokazali, da se je genotip N92-9 bolje odzval na razmere zastajanja vode $\mathrm{v}$ tleh $\mathrm{v}$ vseh preučevanih znakih kot ostala dva analizirana genotipa.

Ključne besede: stres zaradi zastajanja vode $\mathrm{v}$ tleh; antioksidacijski encimi; pšenica; prolin; pridelek: komponenete pridelka

\section{INTRODUCTION}

Waterlogging, which is due to poor drainage of the soil under inappropriate irrigation practices or heavy rainfall, is one of the abiotic stresses and considered as one of the main limitation factors for the growth and yield of crops. Therefore, excess water around the plant's root causes a decrease in oxygen concentration and the plant encounters oxygen deficiency, which is known as hypoxia (Dennis et al., 2000). Plants need to exchange atmospheric gases to maintain their natural growth and photosynthesis and respiration processes (Suzuki and Mittler, 2006). Therefore, under flooding conditions, excess water around the root reduces gas

1 Department of Biology, Basic Science Campus, Science and Research Branch, Islamic Azad University, Tehran, Iran

2 Department of Agronomy, Genetics and Agricultural Biotechnology Institute of Tabarestan, Sari agricultural science and natural resources university, Sari, Iran; *corresponding author: Pirdasht@yahoo.com

3 Agricultural and Natural Resources Research Center of Mazandaran, Iran 
diffusion, which directly affects the absorption of nutrients, plant growth and yield (Fukao and BaileySerres, 2004).

The tolerance to flooding conditions varies in crops that depend on biochemical and anatomical adaptations (Liu et al., 2005). The closure of the stomata to prevent water loss along with the adjustment of photosynthetic apparatus is one of the main responses of the plant under waterlogging stress (Arbona et al., 2008). In addition, under environmental stresses, antioxidant defense systems play an important role in plant tolerance to stress. Reactive oxygen species (ROS) damage the living tissues through the oxidation of biological macromolecules such as lipids, proteins, and nucleic acid (Mittler et al., 2004). By converting ROS to harmless compounds by enzymatic and non-enzymatic antioxidants, the toxic effect of ROS is reduced. The first cellular defense line is superoxide dismutase (SOD) followed by catalase (CAT) and peroxidase (POD) (Edreva, 2005). In various studies, increased activity of antioxidant enzymes has been reported under various environmental stresses (Kumutha et al., 2009; Amador et al., 2012; Gerami et al., 2018). Van Toai and Bolles (1991) showed that high SOD activity with superoxide detoxification could help tolerate the plant under flood stress.
Wheat (Triticum aestivum L.) is one of the most important crops that is widely cultivated under different climatic conditions. Wheat is grown in areas with different moisture conditions where rainfall ranges from 250 to 1800 millimeters. However, the most areas of wheat cultivation receive an average annual rainfall of 380 and 880 millimeters (Herzog et al., 2016). Wheat cultivation requires adequate moisture during the growing season; however, excessive irrigation or precipitation causes waterlogging. According to estimates, more than 10 to 15 million ha of wheat fields are under waterlogging threat (Sayre et al., 1994). Olgun et al. (2008) reported that wheat yield reduced under waterlogging stress. In other study, Collaku and Harrison (2002) examined the effect of different levels of waterlogging $(0,10,20$ and $30 \mathrm{~d})$ on nine wheat cultivars, indicating that waterlogging stress reduced the yield of nine wheat cultivars from 35 to $60 \%$.

The purpose of this study was to evaluate the effects of waterlogging on biochemical traits such as content of chlorophyll $\mathrm{a}$ and $\mathrm{b}$, proline and antioxidant enzymes activity of three wheat-promising lines in two tillering and stem elongation stages. In addition, at physiological maturity, grain yield, number of seeds per spike, grain mass per spike and number of spikes per square meter were investigated.

\section{MATERIALS AND METHODS}

Seeds (20 seeds per pot) of three wheat-promising lines (N-93-19, N-93-9 and N-92-9) were sown in plastic pots (19 $\mathrm{cm}$ depth, $23 \mathrm{~cm}$ diameter). The pots were filled with $4 \mathrm{~kg}$ of sterilized field soil amended with $2.4 \mathrm{~g}$

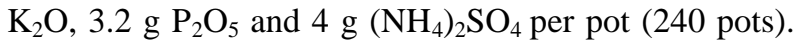
After germination, plants were thinned to 10 plants per pot. Waterlogging treatments included $0,7,14$ and 21 days in tillering (ZG21) and stem elongation (ZG31) stages. In the stem elongation stage, plants of all three genotypes after 21 days of waterlogging were completely died, which were not sampled. Waterlogging stress was applied by placing the pots in larger pots (30 $\mathrm{cm}$ depth, $30 \mathrm{~cm}$ diameter) filled with water to $2 \mathrm{~cm}$ above the surface of the soil. The control plants were watered as much as needed to avoid waterlogging stress and drought stress. At the end of the waterlogging treatments, half of the pots (5 pots) were harvested to measure the biochemical traits, while the remaining pots were grown until physiological maturity. Then seeds/spike, seeds mass/spike, spikes $/ \mathrm{m}^{2}$ and grain yield were measured according to Ceylan (1994).

To measure chlorophyll (a and b) and carotenoids, extracts of fresh leaves with $80 \%$ acetone according to method of Lichtenthaler and Wellburm (1983) were used. For proline measurement, fresh leaves were extracted with methanol (40\%). Then $1 \mathrm{ml}$ of methanolic extract was mixed with $25 \mathrm{ml}$ of ninhydrin and $1 \mathrm{ml}$ of the mixture of orthophosphoric acid (6M) and glacial acetic acid $(2.3 \mathrm{v} / \mathrm{v})$. The tubes were incubated at $100{ }^{\circ} \mathrm{C}$ and after cooling, toluene $(5 \mathrm{ml})$ was added. By reading the absorbance of supernatant at $528 \mathrm{~nm}$ using spectrophotometer (Varian, Carry 300, California, USA), free proline content was calculated according to Bates et al. (1973) method. In order to measure lipid peroxidation, malondialdehyde (MDA) content was determined using thiobarbituric acid method according to Heath and Packer (1968) and an extinction coefficient of $155 \mathrm{mM}^{-1} \mathrm{~cm}^{-1}$.

Fresh leaf samples $(10 \mathrm{~g})$ were homogenized in $100 \mathrm{mM}$ Tris- $\mathrm{HCl}$ ( $\mathrm{pH} 7.5$ ) comprising $5 \mathrm{mM}$ dithiothreitol (DTT), $10 \mathrm{mM}$ magnesium chloride $\left(\mathrm{MgCl}_{2}\right), 1 \mathrm{mM}$ ethylenediaminetetraacetic acid (EDTA), $5 \mathrm{mM}$ $\mathrm{Mg}\left(\mathrm{CH}_{3} \mathrm{COO}\right)_{2} \quad$ (magnesium acetate), $1.5 \%$ polyvinylpyrrolidone $\quad(\mathrm{PVP}), \quad 1 \quad \mathrm{mM}$ phenylmethanesulfonyl fluoride (PMSF), and $1 \mu \mathrm{g} \mathrm{ml}^{-1}$ aproptinin. As the enzyme source, the supernatant separated after centrifugation of homogenate at $15000 \mathrm{~g}$ for 20 minutes has been used. 
The superoxide dismutase (SOD) activity was measured using photo-reduction of NBT (nitrobluetetrazolium). The amount of protein used to inhibit $50 \%$ of the NBT photo-reduction at $560 \mathrm{~nm}$ was considered as one unit of activity of SOD enzyme. The protocol of Luck (1971) has been applied for determination of catalase (CAT) activity by using the rate of decrease in absorbance at $240 \mathrm{~nm}$ for two minutes. Meahly and Chance (1954) method was used to measure the peroxidase (POD) activity based on the oxidation of guaiacol in the presence of hydrogen peroxide $\left(\mathrm{H}_{2} \mathrm{O}_{2}\right)$. All spectrophotometric experiments were performed using a Varian, Carry 300, California, USA spectrophotometer.

Two-way ANOVA has been used for the analysis of the results by with SAS 9.1.3 software and means were compared with the LSD test $(\mathrm{P}<0.05)$.

\section{RESULTS}

\subsection{Photosynthetic pigments}

In tillering and stem elongation stages, waterlogging treatments reduced the content of chlorophyll $\mathrm{a}$ and $\mathrm{b}$ in all three wheat genotypes. The highest reduction of chlorophylls was observed during 14 and $21 \mathrm{~d}$ waterlogging in tillering and stem elongation stages, respectively. In all treatments, N-93-19 and N-92-9 genotypes had the highest and lowest reductions, respectively, as compared to the corresponding control (Fig 1 and 2). In the tillering stage, carotenoids contents decreased in N-93-19 genotype by $15.45,37.55$ and $67.38 \%$, in N-93-9 genotype by $14.88,26.48$ and
$53.61 \%$, in N-92-9 genotypes by $11.03,15.86$ and $28.96 \%$ under treatment of 7,14 and $21 \mathrm{~d}$ waterlogging, respectively as compared to the corresponding controls (Fig 3 A). $7 \mathrm{~d}$ waterlogging in stem elongation stage reduced carotenoids in all three wheat genotypes, but there was no significant difference between the three wheat genotypes. $14 \mathrm{~d}$ waterlogging treatment reduced carotenoids contents in N-93-19, N93-9 and N-92-9 by 49.14, 35.5 and $32.15 \%$, respectively, as compared to the corresponding controls (Fig 3 B).

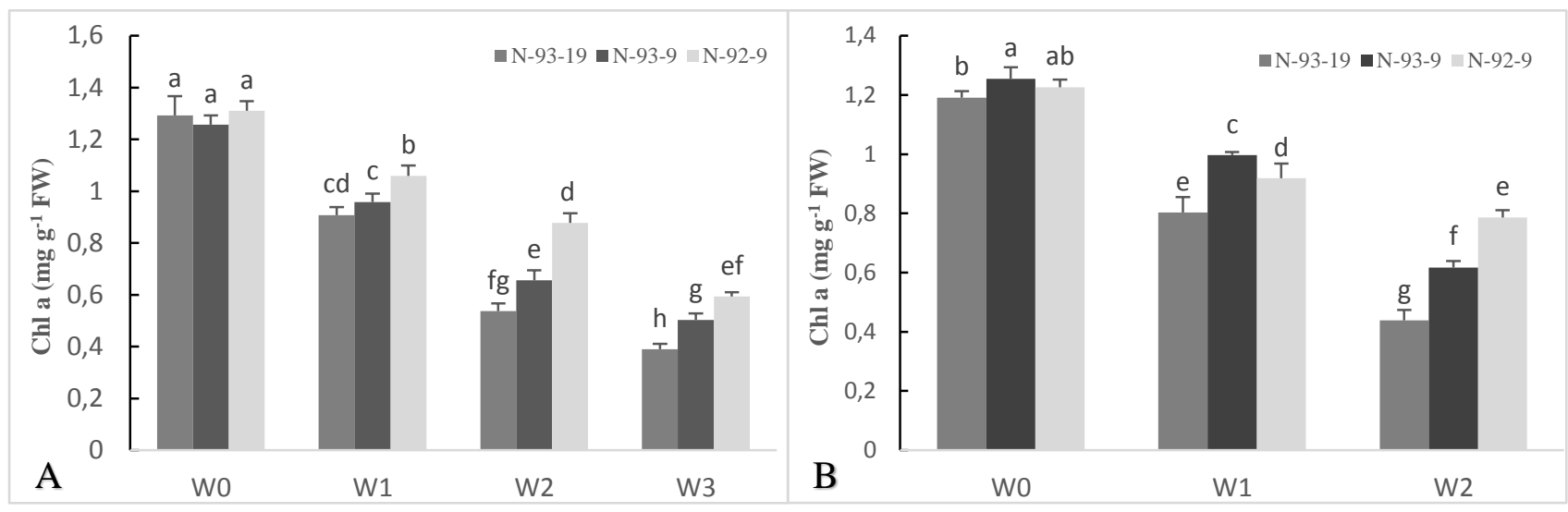

Figure 1: Effect of waterlogging (W0: 0, W1: 7, W3: 14 and W4: 21 d) on contents of chlorophyll a in wheat genotypes in tillering (A) and stem elongation (B) stages. Means followed by the same letter are not significantly different $(\mathrm{P}<0.05)$ according to LSD test $(\mathrm{n}=5)$ 


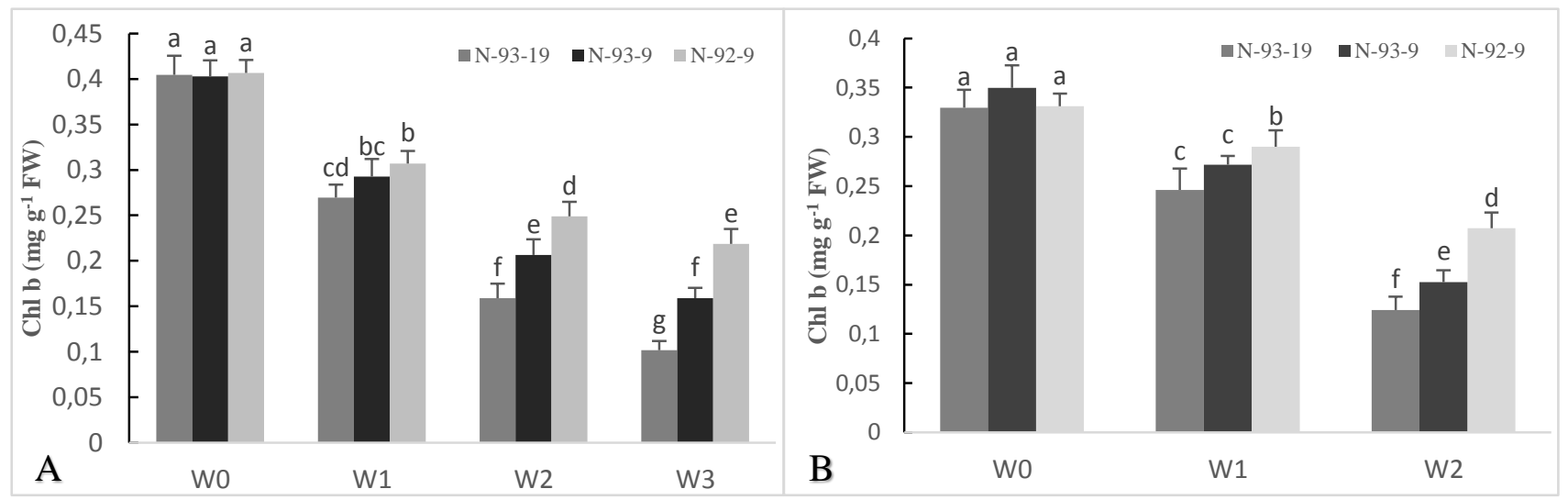

Figure 2: Effect of waterlogging (W0: 0, W1: 7, W3: 14 and W4: 21 d) on contents of chlorophyll b in wheat genotypes in tillering (A) and stem elongation (B) stages. Means followed by the same letter are not significantly different $(\mathrm{P}<0.05)$ according to LSD test $(\mathrm{n}=5)$

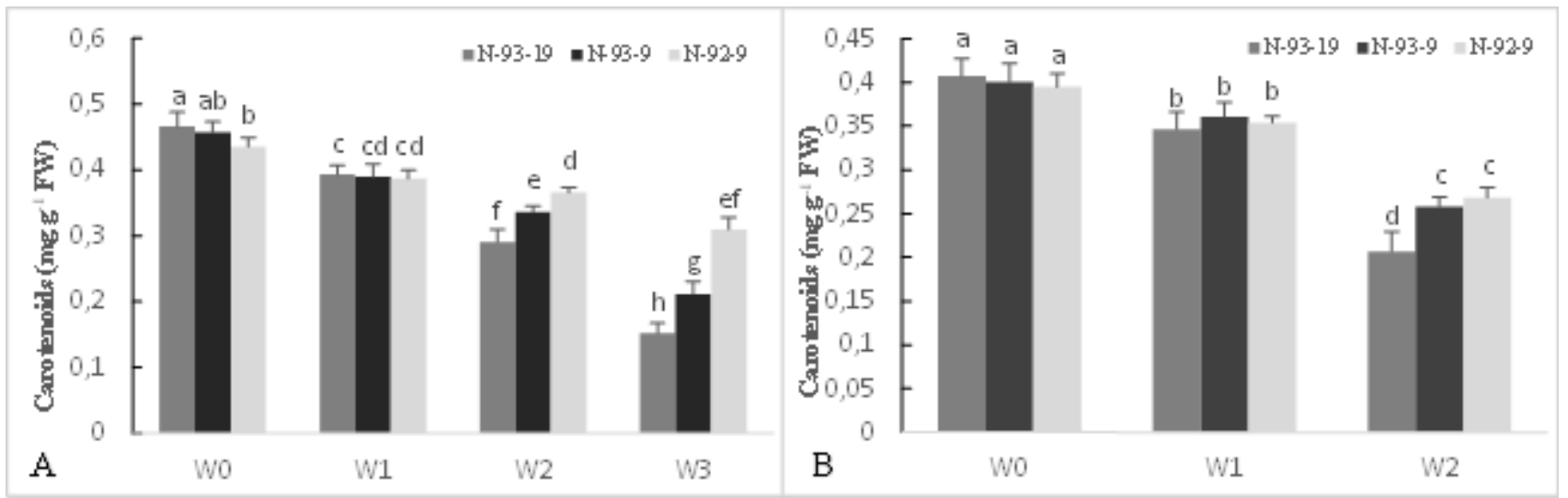

Figure 3: Effect of waterlogging (W0: 0, W1: 7, W3: 14 and W4: 21 d) on contents of carotenoids in wheat genotypes in tillering (A) and stem elongation (B) stages. Means followed by the same letter are not significantly different $(P<0.05)$ according to LSD test $(n=5)$

\subsection{Proline and MDA contents}

Waterlogging treatments in tillering stage $(4,7$ and 21 d) and stem elongation stage (7 and $14 \mathrm{~d})$ resulted in significant increase of proline contents in all three wheat genotypes. The highest increase was observed in N-92-9 genotype (Fig 4). The waterlogging-induced oxidative stress results in lipid peroxidation and damage to the membrane, evaluated as MDA, representing possible damage. MDA contents in both growth stages under waterlogging treatment showed a significant increase in all three wheat genotypes as compared to corresponding controls and N-93-19 genotype showed the highest increase compared to other wheat genotypes (Fig 5). Proline and MDA contents also increased with increasing waterlogging duration, so that the highest proline and MDA contents were observed in the tillering stage under $21 \mathrm{~d}$ waterlogging and in stem elongation stage under $14 \mathrm{~d}$ waterlogging (Fig 4 and 5). 


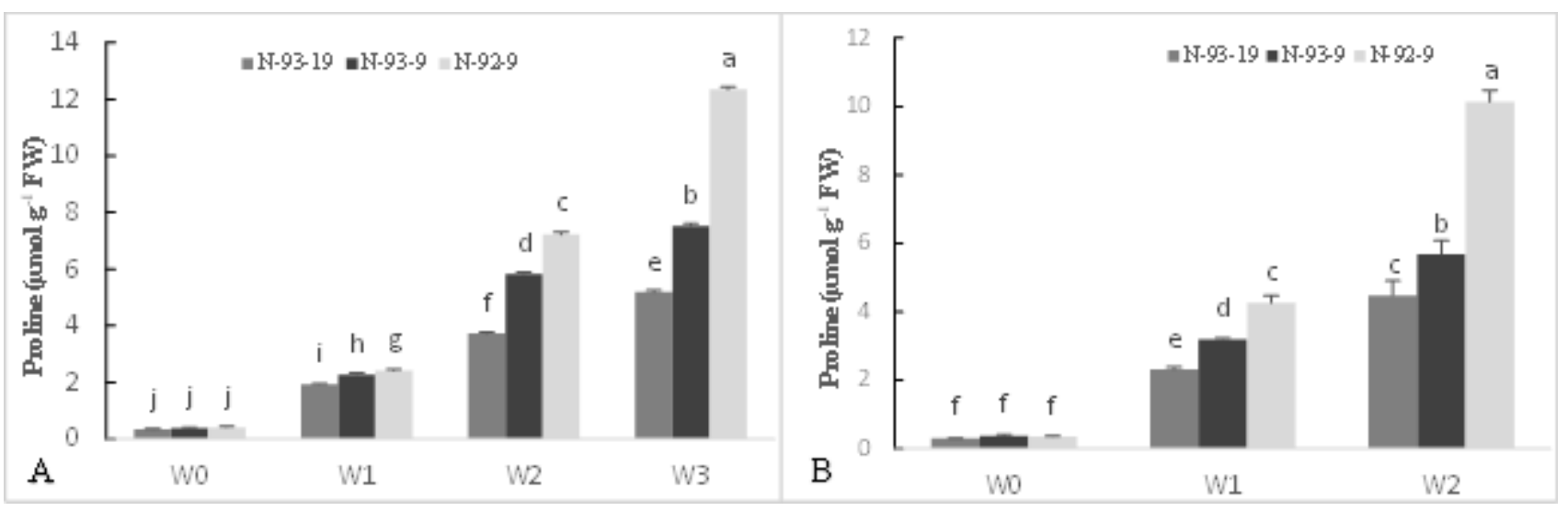

Figure 4: Effect of waterlogging (W0: 0, W1: 7, W3: 14 and W4: $21 \mathrm{~d}$ ) on contents of proline in wheat genotypes in tillering (A) and stem elongation (B) stages. Means followed by the same letter are not significantly different $(\mathrm{P}<$ $0.05)$ according to LSD test $(n=5)$

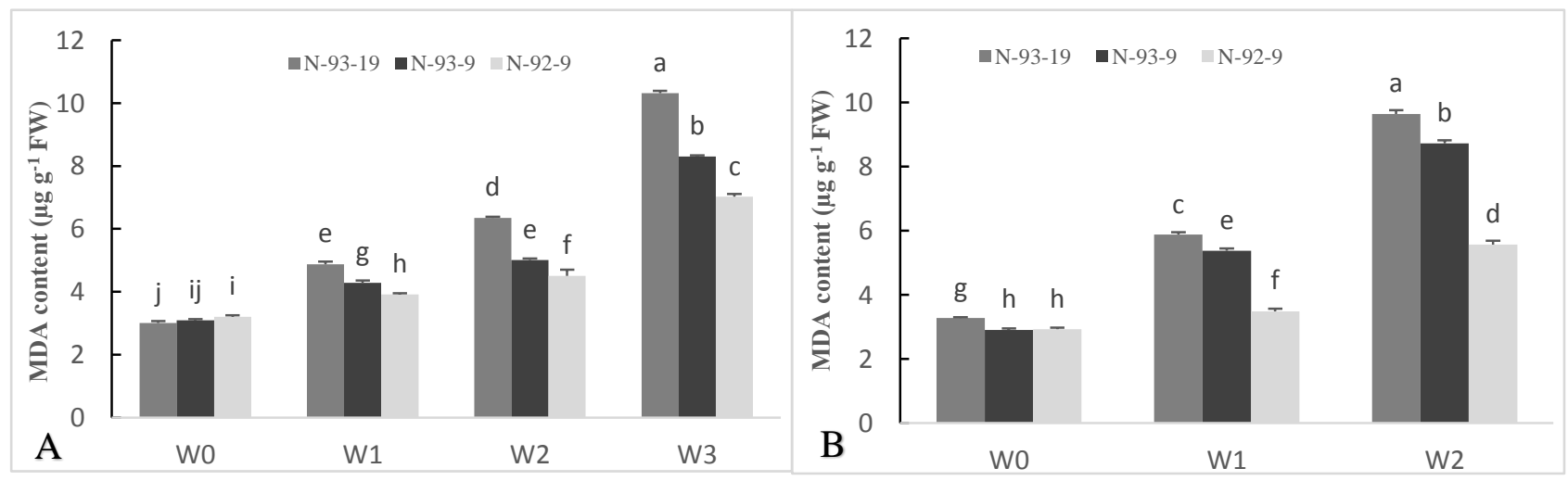

Figure 5: Effect of waterlogging (W0: 0, W1: 7, W3: 14 and W4: $21 \mathrm{~d}$ ) on contents of MDA in wheat genotypes in tillering (A) and stem elongation (B) stages. Means followed by the same letter are not significantly different (P < $0.05)$ according to LSD test $(n=5)$

\subsection{Antioxidant activity}

Waterlogging treatment in the tillering stage significantly increased the activity of SOD enzyme in all three wheat genotypes. At tillering stage, the highest increase in N-93-9, N-92-9 and N-93-19 genotypes observed under $21 \mathrm{~d}$ waterlogging by $73.67,79.55$ and $66.99 \%$, respectively as compared to the corresponding control (Fig 6 A). In stem elongation stage, the waterlogging stress increased the activity of the SOD and the highest activity of SOD observed in N-92-9 genotype under $14 \mathrm{~d}$ waterlogging (Fig $6 \mathrm{~B}$ ). In all three wheat genotypes, waterlogging treatment significantly reduced the activity of POD enzyme in stem elongation and tillering stages. There was no significant difference between wheat genotypes in the tillering stage, however, in the stem elongation stage, the highest decrease of POD activity observed in N-93-19 genotype under $14 \mathrm{~d}$ waterlogging (Fig 7). The results of CAT activity in the tillering stage indicated that the waterlogging treatment reduced the activity of CAT in N-93-19 and N-93-9 genotypes, while the activity of this enzyme under the waterlogging conditions in N-929 genotype had a significant increase as compared to the control (Fig 8 A). The results of CAT enzyme activity in stem elongation stage indicated that wheat genotypes responded differently to waterlogging stress. In N-93-19 genotype, waterlogging treatment reduced the activity of CAT enzyme and the highest reduction observed for $14 \mathrm{~d}$ waterlogging. CAT enzyme activity in N-93-9 genotype significantly increased under $7 \mathrm{~d}$ waterlogging than control, but decreased under 14 days of waterlogging. There was no significant difference in CAT activity in N-92-9 genotype under different waterlogging durations (Fig 8 B). 
Fereshteh ALIZADEH-VASKASI et al.

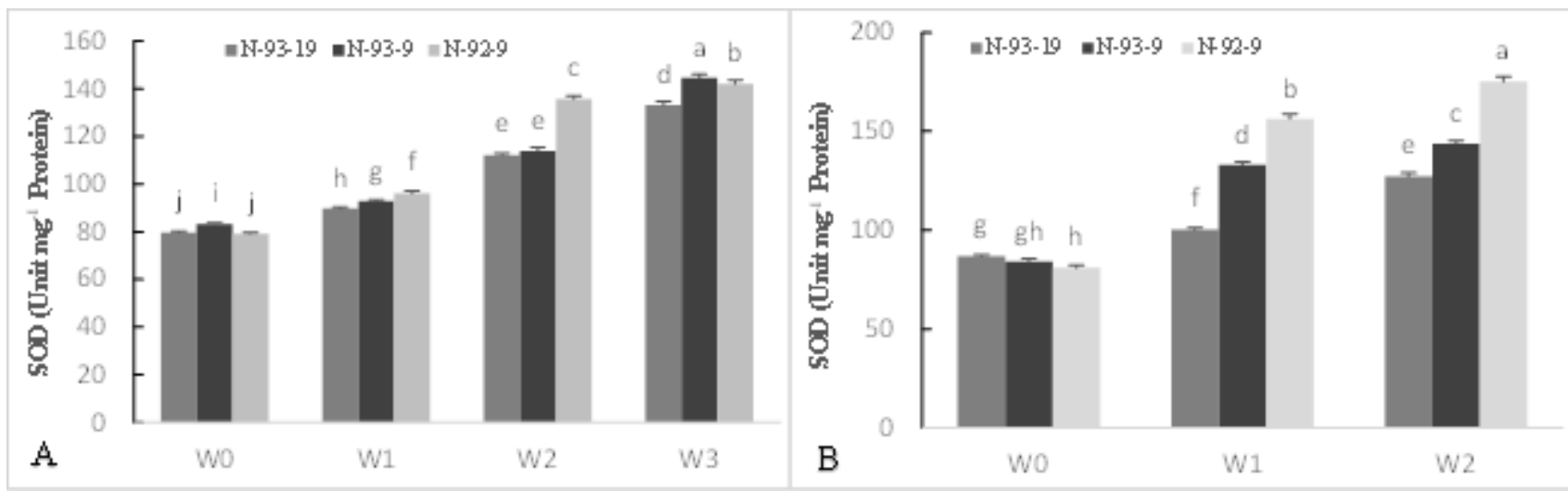

Figure 6: Effect of waterlogging (W0: 0, W1: 7, W3: 14 and W4: 21 d) on SOD activity in wheat genotypes in tillering (A) and stem elongation (B) stages. Means followed by the same letter are not significantly different $(\mathrm{P}<$ $0.05)$ according to LSD test $(n=5)$.

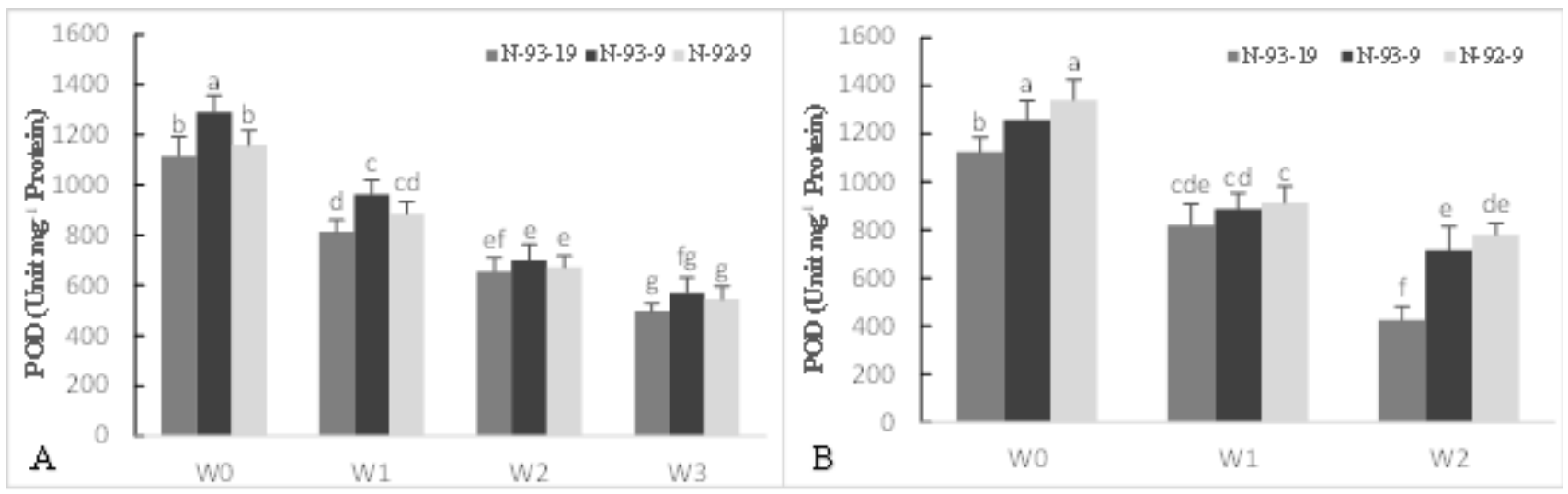

Figure 7: Effect of waterlogging (W0: 0, W1: 7, W3: 14 and W4: 21 d) on POD activity in wheat genotypes in tillering (A) and stem elongation (B) stages. Means followed by the same letter are not significantly different $(\mathrm{P}<$ $0.05)$ according to LSD test $(n=5)$.

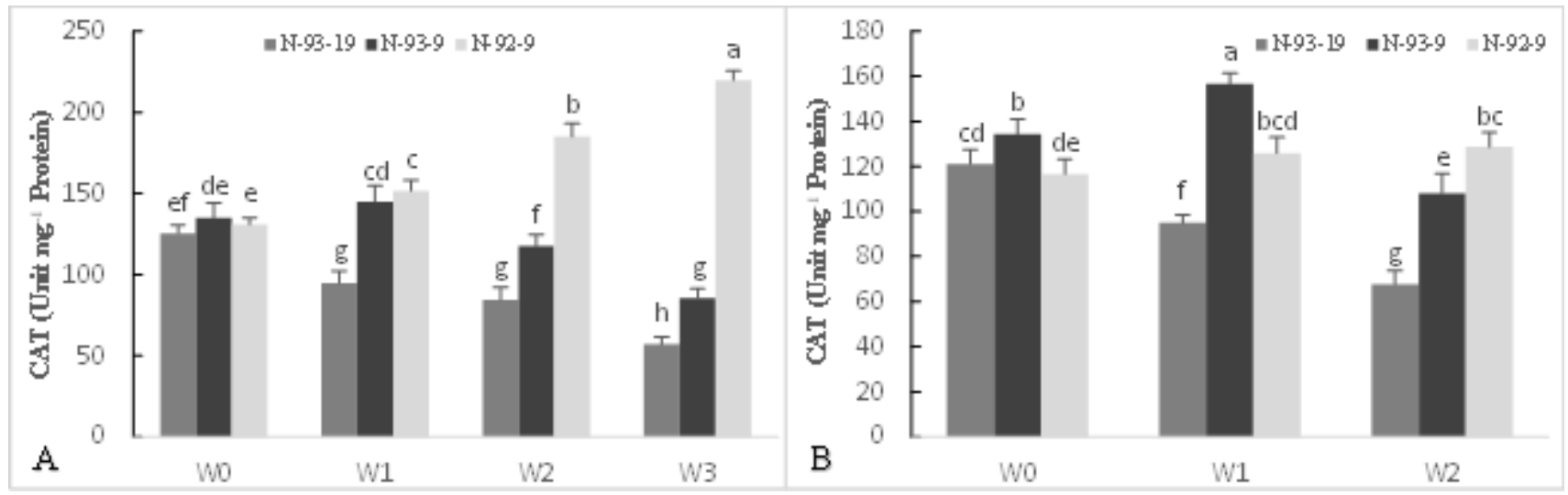

Figure 8: Effect of waterlogging (W0: 0, W1: 7, W3: 14 and W4: 21 d) on CAT activity in wheat genotypes in tillering (A) and stem elongation (B) stages. Means followed by the same letter are not significantly different $(\mathrm{P}<$ $0.05)$ according to LSD test $(n=5)$ 


\subsection{Yields and yield components}

In tillering and stem elongation stages, waterlogging treatments decreased kernels/spike and kernels mass/spike in all three wheat genotypes. The highest decline of kernels/spike and kernels mass/spike were observed during 14 and $21 \mathrm{~d}$ waterlogging in tillering and stem elongation stages, respectively. In all treatments, N-93-19 and N-92-9 genotypes had the highest and lowest reductions, respectively as compared to the corresponding control (Fig 9 and 10). Waterlogging treatment in the tillering stage significantly reduced grain yield in all three wheat genotypes. At tillering stage, the highest decline in N93-9, N-92-9 and N-93-19 genotypes observed under 21 $\mathrm{d}$ waterlogging by $60.15,56.01$ and $37.08 \%$, respectively as compared to the corresponding control (Fig $11 \mathrm{~A})$. In stem elongation stage, the waterlogging stress decreased the grain yield and the highest reduction observed in N-93-19 genotype under $14 \mathrm{~d}$ waterlogging (Fig $11 \mathrm{~B}$ ). The spikes $/ \mathrm{m}^{2}$ is an important criterion for assessing the effect of stress on wheat yield. In tillering and stem elongation stages, waterlogging treatments reduced the spikes $/ \mathrm{m}^{2}$ in all three wheat genotypes. The highest reduction in spike $/ \mathrm{m}^{2}$ were observed during 14 and $21 \mathrm{~d}$ waterlogging in tillering and stem elongation stages, respectively. In all treatments, N-92-9 and N-93-19 genotypes had the lowest and highest reductions, respectively as compared to the corresponding control (Fig 12).

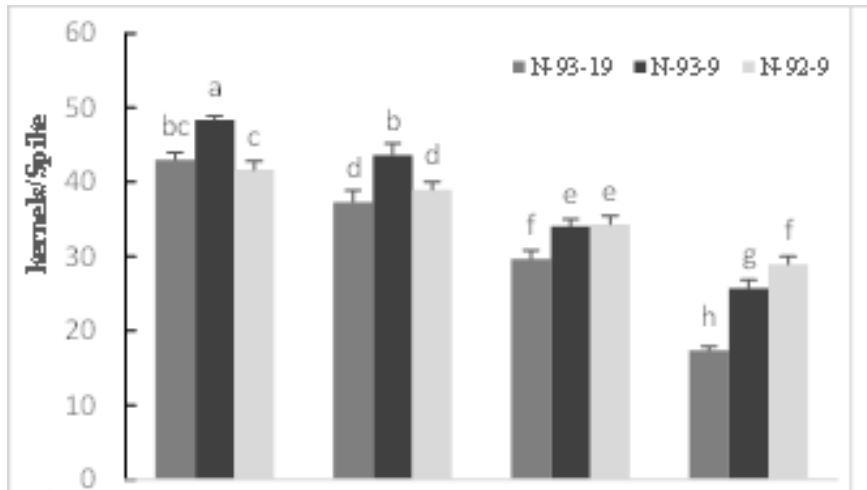

A wo W1 w2 w3

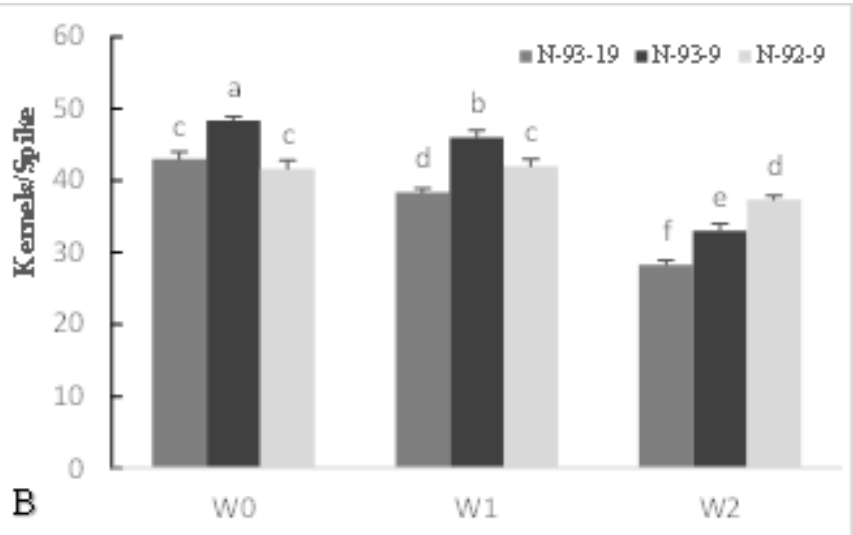

Figure 9: Effect of waterlogging (W0: 0, W1: 7, W3: 14 and W4: 21 d) on kernels/spike in wheat genotypes in tillering (A) and stem elongation (B) stages. Means followed by the same letter are not significantly different (P < $0.05)$ according to LSD test $(n=5)$
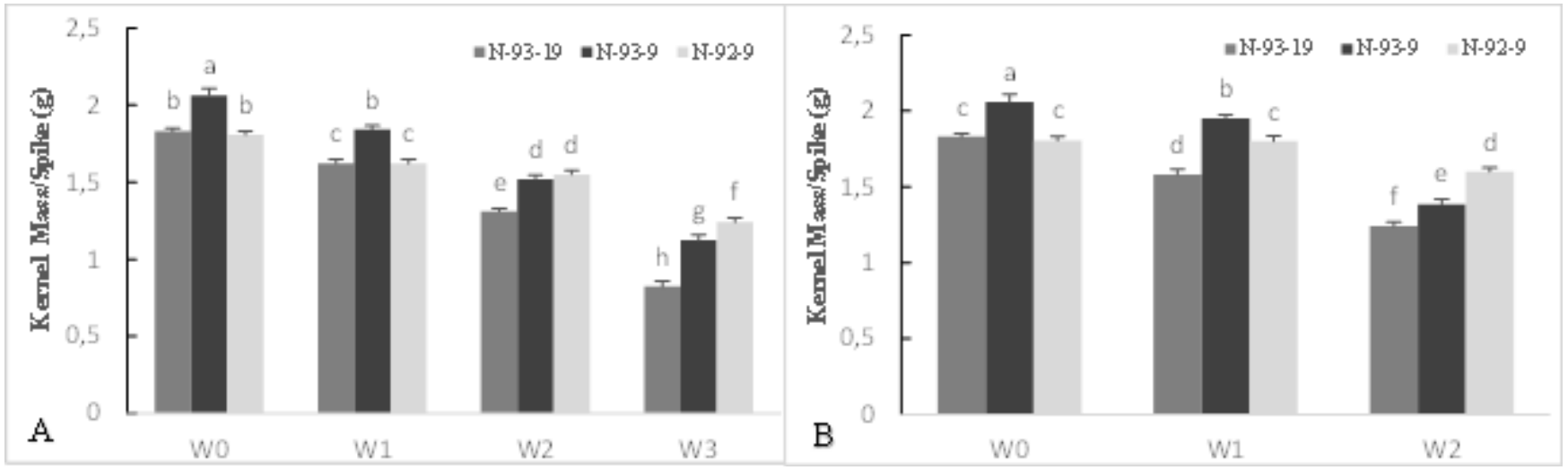

Figure 10: Effect of waterlogging (W0: 0, W1: 7, W3: 14 and W4: 21 d) on kernels mass/spike in wheat genotypes in tillering (A) and stem elongation (B) stages. Means followed by the same letter are not significantly different (P $<0.05)$ according to LSD test $(\mathrm{n}=5)$ 


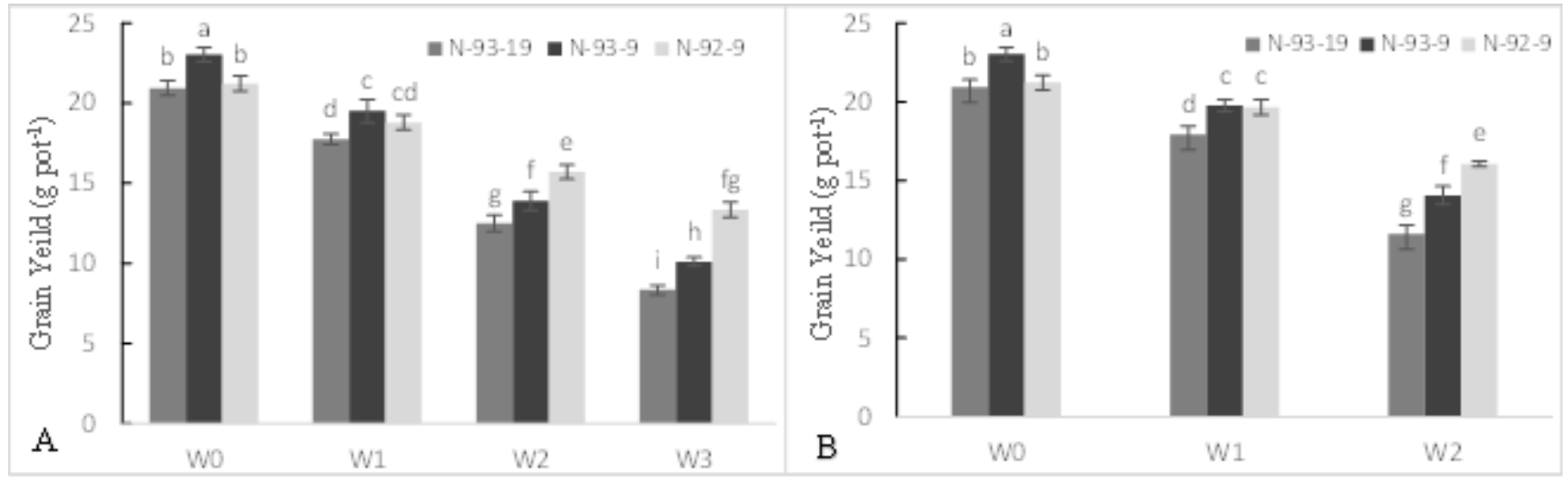

Figure 11: Effect of waterlogging (W0: 0, W1: 7, W3: 14 and W4: 21 d) on grain yield in wheat genotypes in tillering (A) and stem elongation (B) stages. Means followed by the same letter are not significantly different $(\mathrm{P}<$ $0.05)$ according to LSD test $(\mathrm{n}=5)$

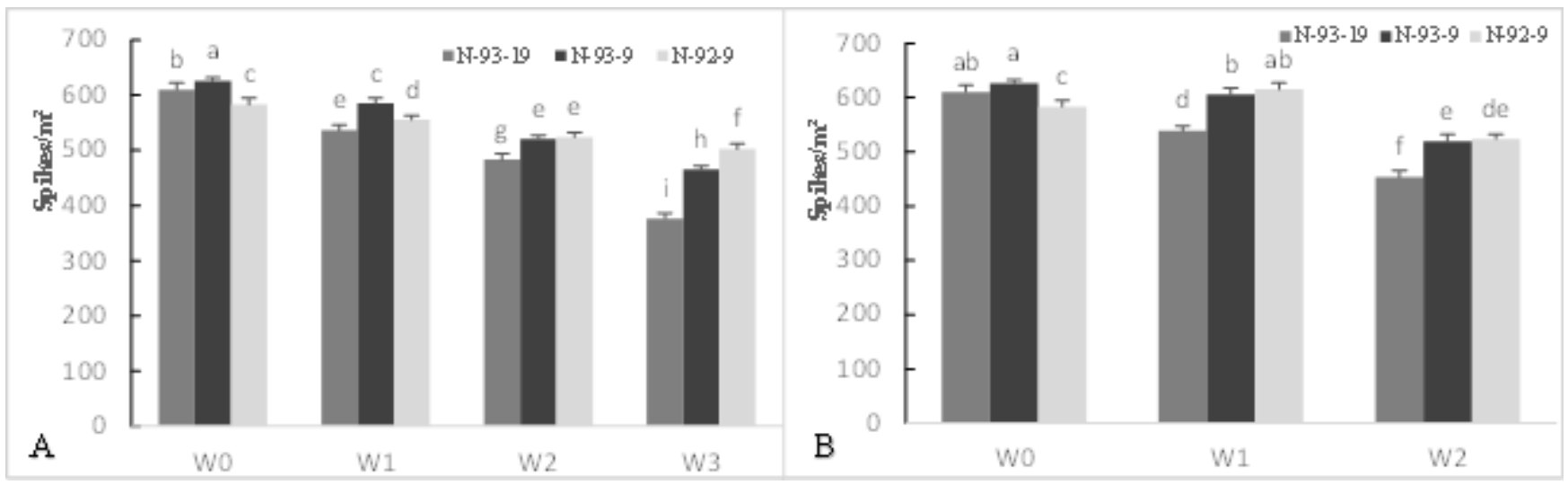

Figure 12: Effect of waterlogging (W0: 0, W1: 7, W3: 14 and W4: $21 \mathrm{~d}$ ) on spikes $/ \mathrm{m}^{2}$ in wheat genotypes in tillering (A) and stem elongation (B) stages. Means followed by the same letter are not significantly different $(\mathrm{P}<0.05)$ according to LSD test $(\mathrm{n}=5)$

\section{DISCUSSION}

High chlorophyll content under waterlogging conditions can be the most appropriate way for achieving high yield under waterlogging conditions (Gardner et al., 1993). Our results indicated that waterlogging treatments in tillering and stem elongation stages significantly reduced photosynthetic pigments (chl a, b and carotenoids) in all three wheat genotypes, however, N-92-9 genotype had higher photosynthetic pigments than other genotypes under all waterlogging duration. Pang et al. (2004) stated that waterlogging stress reduced the content of chlorophyll and consequently reduced the rate of $\mathrm{CO}_{2}$ assimilation. In another report, Smethurst and Shabala, (2003) indicated that the content of chlorophyll $\mathrm{a}$ and $\mathrm{b}$ reduced in genotypes under waterlogging treatments. Screening of the effect of waterlogging duration on chlorophyll and carotenoids content presented that by increasing the duration of waterlogging, the content of chlorophyll and carotenoids more decreased, which is according to the results of Olgun et al. (2008).

The maintaining of water balance of the plant under environmental stresses is very important for plant tolerance, which proline is one of the most compatible solutes (Claussen, 2005; Ghorbani et al., 2018). Our results showed that proline contents under waterlogging stress increased in tillering and stem elongation stages. The increase of proline contents in N-92-9 genotype was significantly higher than the other two varieties under same waterlogging duration. Increasing of waterlogging duration significantly increased the contents of proline, which is in accordance to results of Olgun et al. (2008). Increasing proline contents in plants under waterlogging treatments can be due to oxidation inhibition, loss of inhibition of feedback and protein synthesis impairment. Videmšek et al. (2006) reported 
that wheat genotypes have different ability to synthesize and accumulate proline, which affects their tolerance to waterlogging.

The stomatal closure and the reduction of $\mathrm{CO}_{2}$ availability resulting from waterlogging conditions increase the production of reactive oxygen species (ROS) and thus induce oxidative stress (Gossett et al., 1994). Our results showed that waterlogging stress increased MDA production, which indicating the degree of damage to membrane lipids. However, there was a significant difference between wheat genotypes, which indicates their different defensive capacity against waterlogging-induced ROS. Increasing the activity of antioxidant enzymes such as SOD, CAT and POD can play an important role in plant tolerance to waterlogging stress. The results of this study showed a continuous increase in the activity of SOD and a decrease in the activity of POD in all three wheat genotypes under waterlogging stress. However, CAT activity under waterlogging treatments in N-92-9 genotype showed a continuous increase while there was decline in CAT activity in two genotypes of N-93-19 and N-93-9. Different researchers have suggested that the activity of antioxidant enzymes under waterlogging conditions increases to take care of hypoxia-induced oxidative stress (Arbona et al., 2008; Kumutha et al., 2009). Our results are in accordance with the results of Blokhina et al. (2001) who found more oxidative stress under waterlogging and increased antioxidant enzymes could reduce ROS production. It is clear from the results that wheat genotypes suffered from ROS under waterlogging stress that intensified with increasing the waterlogging duration. Therefore, the rapid increase in the activity of antioxidant enzymes in plants under waterlogging stress can protect the plant against the oxidative stress caused by waterlogging. Many researchers have been previously reported increased activity of CAT (Ushimaru et al., 1997), POD (Meloni et al., 2003) and SOD (VanToai and Bolles, 1991, Biemelt et al., 2000) enzymes under waterlogging conditions.

Kernels mass/spike is one of the most important components of wheat yield. Our results showed that waterlogging treatments reduced the kernels/spike and kernels mass/spike traits of all three studied wheat genotypes in both tillering and stem elongation stages, however, the lowest decrease was observed in N-92-9 genotype. These findings are consistent with the results of Collaku and Harrison (2002) who stated that increasing the duration of waterlogging reduce the kernels/spike. They also showed that tolerant genotypes had higher kernels/spike compared to other genotypes. In another report, Saqib et al. (2004) showed that the kernels mass/spike in wheat genotypes under waterlogging stress was reduced by $50-80 \%$ as compared to control treatments. The results related to yield and spikes $/ \mathrm{m}^{2}$ showed that these traits significantly decreased with increasing waterlogging duration in all three genotypes and the highest decrease was observed in N-93-19 genotype. Reducing the yield of wheat genotypes under waterlogging according to BarretLennard (2003) and Setter et al. (2001) who showed that increasing waterlogging duration reduced wheat yield from 10 to $80 \%$. Collaku and Harrison (2002) also reported that waterlogging stress reduced the spikes $/ \mathrm{m}^{2}$ in winter wheat.

\section{CONCLUSION}

In general, the results showed that waterlogging stress caused oxidative stress in wheat genotypes that enhanced with duration of exposure. N-92-9 genotype with higher activity of antioxidant enzymes (CAT, SOD and POD) which resulted in higher grain yield and yield components under waterlogging conditions was more tolerant to waterlogging stress.

\section{REFERENCES}

Amador, M.L., Sancho, S., Bielsa, B., Gomez-Aparisi, J., Rubio-Cabetas, M.J. (2012). Physiological and biochemical parameters controlling waterlogging stress tolerance in Prunus before and after drainage. Physiologia Plantarum, 144, 357-368. doi:10.1111/j.1399-3054.2012.01568.x

Arbona, V., Hossain, Z., Lo'pez-Climent, M.F., Pe'rezClemente, R.M., Go'mez-Cadenas, A. (2008). Antioxidant enzymatic activity is linked to waterlogging stress tolerance in citrus. Physiologia
Plantarum, 132, 452-466. doi:10.1111/j.13993054.2007.01029.x

Barret-Lennard, E.G. (2003). The interaction between waterlogging and salinity in higher plants: causes, consequences and implications. Plant and Soil, 253, 35-54. doi:10.1023/A:1024574622669

Bates, L., Waldren, R.P., Teatre, J.D. (1973). Rapid determination of free proline for water stress studies. Plant and Soil, 39, 205-207. doi:10.1007/BF00018060 
Biemelt, S., Keetman, U., Mock, H.P., Grimm, B. (2000). Expression and activity of isoenzymes of superoxide dismutase in wheat roots in response to hypoxia and anoxia. Plant, Cell \& Environment, 23, 135-144. doi:10.1046/j.1365-3040.2000.00542.x

Blokhina, O.B., Fagerstedt, K.V., Chirkova, T.V. (1999). Relationships between lipid peroxidation and anoxia tolerance in a range of species during post-anoxic reaeration. Physiologia Plantarum, 105, 625-632. doi:10.1034/j.13993054.1999.105405.x

Ceylan, A. (Ed) (1994). Field Crop Production. Aegean University Press, Izmir, pp. 520.

Claussen, W. (2005). Proline as a measure of stress in tomato plants. Plant Science, 168, 241-248. doi:10.1016/j.plantsci.2004.07.039

Collaku, A., Harrison, S.A. (2002). Losses in wheat due to waterlogging. Crop Science, 42, 444-450. doi:10.2135/cropsci2002.4440

Dennis, E.S., Dolferus, R., Ellis, M., Rahman, M., Wu, Y., Hoeren, F.U., Grover, A., Ismond, K.P., Good, A.G., Peacock, W.J. (2000). Molecular strategies for improving waterlogging tolerance in plants. Journal of Experimental Botany, 342, 89-97. doi:10.1093/jexbot/51.342.89

Edreva, A. (2005). Generation and scavenging of reactive oxygen species in chloroplasts: a submolecular approach. Agriculture, Ecosystems \& Environment, $\quad 106, \quad 119-133$. doi:10.1016/j.agee.2004.10.022

Fukao, T., Bailey-Serres, J. (2004). Plant responses to hypoxia - is survival a balancing act? Trends in Plant Science, $9, \quad 449-456$. doi:10.1016/j.tplants.2004.07.005

Gardner, W.K., Flood, R.G. (1993). Less waterlogging damage with long season wheats. Cereal Research Communications, 21, 337-343.

Gerami, M., Ghorbani, A., Karimi, S. (2018). Role of salicylic acid pretreatment in alleviating cadmiuminduced toxicity in Salvia officinalis L. Iranian Journal of Plant Biology, 10(1), 81-95.

Ghorbani, A., Razavi, S.M., Ghasemi Omran, V.O., Pirdashti, H. (2018). Piriformospora indica inoculation alleviates the adverse effect of $\mathrm{NaCl}$ stress on growth, gas exchange and chlorophyll fluorescence in tomato (Solanum lycopersicum L.). $\begin{array}{lll}\text { Plant } \quad \text { Biology, } & \text { 20(4), }\end{array}$ doi:10.1111/plb.12717

Gossett, D.R., Millhollon, E.P., Lucas, M.C. (1994). Antioxidant response to $\mathrm{NaCl}$ stress in salt-tolerant and salt-sensitive cultivars of cotton. Crop Science,
34 ,

706-714

doi:10.2135/cropsci1994.0011183X003400030020

$\mathrm{x}$

Herzog, M., Striker, G.G., Colmer, T.D., Pedersen, O. (2016). Mechanisms of waterlogging tolerance in wheat--a review of root and shoot physiology. Plant, Cell \& Environment, 39(5), 1068-86. doi:10.1111/pce.12676

Kumutha, D., Ezhilmathi, K., Sairam, R.K., Srivastava, G.C., Deshmukh, P.S., Meena, R.C. (2009). Waterlogging induced oxidative stress and antioxidant activity in pigeonpea genotypes. Physiologia Plantarum, 53(1), 75-84. doi:10.1007/s10535-009-0011-5

Lichtenthaler, H., Wellburm, A.R. (1983). Determination of total carotenoids and chlorophyll $\mathrm{a}$ and $\mathrm{b}$ of leaf extracts in different solvents. Biochemical Society Transactions, 603, 591-593. doi:10.1042/bst0110591

Liu, F., Van Toai, T., Moy, L.P., Bock, G., Linford, L.D., Quackenbush, J. (2005). Global transcription profiling reveals comprehensive insights into hypoxic response in Arabidopsis. Plant Physiology, 137, 1115-1129. doi:10.1104/pp.104.055475

Heath, R.L., Packer, L. (1968). Photoperoxidation in isolated chloroplasts. Archives of Biochemistry and Biophysics, 125(1), 189-198. doi:10.1016/00039861(68)90654-1

Luck, H. 1971. Catalase. In: Bergmeyer HU, editor. Methods of Enzymatic Analysis. New York: Academic Press. pp. 885-894.

Maehly, A.C., Chance, B. (1954). The assay of catalases and peroxidases. Methods of Biochemical Analysis, 1, 357-424. doi:10.1002/9780470110171.ch14

Meloni, D.A., Oliva, M.O., Martinez, C.A., Cambraia, J. (2003). Photosynthesis and activity of superoxide dismutase, peroxidase and glutathione reductase in cotton under salt stress. Environmental and Experimental Botany, 49, 69-76. doi:10.1016/S0098-8472(02)00058-8

Mittler, R., Vanderauwera, S., Gollery, M., Van Breusegem, F. (2004). Reactive oxygen gene network of plants. Trends in Plant Science, 9, 490498. doi:10.1016/j.tplants.2004.08.009

Olgun, M., Kumlay, A.M., Adiguzel, M.C., Caglar, A. (2008). The effect of waterlogging in wheat (T.aestivum L.). Acta Agriculturae Scandinavica Section B-Soil and Plant Science, 58(3), 193-198.

Pang, J., Zhou, M., Mendham, N., Shabala, S. (2004). Growth and physiological responses of six barley genotypes to waterlogging and subsequent 
recovery. Australian Journal of Agricultural Research, 55, 895-906. doi:10.1071/AR03097

Saqib, M., Akhtar, J., Qureshi, R.H. (2004). Pot study on wheat growth in saline and waterlogged compacted soil. Soil \& Tillage Research, 77, 169177. doi:10.1016/j.still.2003.12.004

Sayre, K.D., Van Ginkel, M., Rajaram, S., OrtizMonasterio, I. (1994). Tolerance to waterlogging losses in spring bread wheat: effect of time of onset on expression. Annual Wheat Newsletter, 40, 165171.

Setter, T.L., Burgess, P., Waters, I., Kuo, J. (2001). Genetic diversity of barley and wheat for waterlogging tolerance in Western Australia. In: Proceedings of the 10th Australian Barley Technical Symposium, Canberra, 16-20 September 2001, ACT, Australia.

Smethurst, C.F., Shabala, S. (2003). Screening methods for waterlogging tolerance in lucerne: comparative analysis of waterlogging effects on chlorophyll fluorescence, photosynthesis, biomass and chlorophyll content. Functional Plant Biology, 30, 335-343. doi:10.1071/FP02192

Suzuki, N., Mittler, R. (2006). Reactive oxygen species and temperature stresses: a delicate balance between signaling and destruction. Physiologia Plantarum, 126, 45-51. doi:10.1111/j.00319317.2005.00582.x

Ushimaru, T., Maki, Y., Sano, S., Koshiba, K., Asada, K., Tsuji, H. (1997). Induction of enzymes involved in the ascorbate-dependent antioxidative system, namely ascorbate peroxidase, mono dehydroascorbate reductase and dehydroascorbate reductase, after exposure to air of rice (Oryza sativa) seedlings germinated under water. Plant and Cell Physiology, 38, 541-549. doi:10.1093/oxfordjournals.pcp.a029203

Van Toai, T.T., Bolles, C.S. (1991). Postanoxic injury in soybean (Glycine max) seedlings. Plant Physiology, 97, 588-592. doi:10.1104/pp.97.2.588

Videmšek, U., Turk, B., Vodnik, D. (2006). Root aerenchyma-formation and function. Acta Agriculturae Slovenica, 87, 445-453. 